\title{
Staphylococcus aureus $\alpha$-toxin-induced cell death: predominant necrosis despite apoptotic caspase activation
}

\author{
F Essmann $^{1,3}$, H Bantel ${ }^{1,4,3}$, G Totzke ${ }^{1}$, IH Engels ${ }^{1,5}$, B Sinha ${ }^{2}$, \\ $K$ Schulze-Osthoff ${ }^{1}$ and RU Jänicke ${ }^{*}, 1$ \\ 1 Institute of Molecular Medicine, University of Düsseldorf, Germany \\ 2 Institute of Medical Microbiology, University of Münster, Germany \\ 3 These two authors contributed equally to this work. \\ ${ }^{4}$ Current address: Department of Gastroenterology and Hepatology, Medical \\ University of Hannover, Germany \\ ${ }^{5}$ Current address: Genomics Institute of the Novartis Research Foundation, \\ Department of Cancer and Cell Biology, 10675 John Jay Hopkins Drive, San \\ Diego, CA 92121, USA \\ * Corresponding author: RU Jänicke, Institute of Molecular Medicine, University \\ of Düsseldorf, Universitätsstrasse 1, Bldg. 23.12, 40225 Düsseldorf, Germany. \\ Tel: + 492118115895 ; Fax: + 492118115892 ; \\ E-mail: janicke@uni-duesseldorf.de
}

Received 06.3.03; revised 11.6.03; accepted 19.6.03; published online 1 August 2003 Edited by RA Knight

\begin{abstract}
Recent data suggest that $\alpha$-toxin, the major hemolysin of Staphylococcus aureus, induces cell death via the classical apoptotic pathway. Here we demonstrate, however, that although zVAD-fmk or overexpression of Bcl-2 completely abrogated caspase activation and internucleosomal DNA fragmentation, they did not significantly affect $\alpha$-toxin-induced death of Jurkat T or MCF-7 breast carcinoma cells. Caspase inhibition had also no effect on $\alpha$-toxin-induced lactate dehydrogenase release and ATP depletion. Furthermore, whereas early assessment of apoptosis induction by CD95 resulted solely in the generation of cells positive for active caspases that were, however, not yet permeable for propidium iodide, a substantial proportion of $\alpha$-toxin-treated cells were positive for both active caspases and PI. Finally, electron microscopy demonstrated that even in the presence of active caspases, $\alpha$-toxin-treated cells displayed a necrotic morphology characterized by cell swelling and cytoplasmic vacuolation. Together, our data suggest that $\alpha$-toxin-induced cell death proceeds even in the presence of activated caspases, at least partially, in a caspase-independent, necrotic-like manner. Cell Death and Differentiation (2003) 10, 1260-1272, doi:10.1038/ sj.cdd. 4401301

Published online 1 August 2003
\end{abstract}

Keywords: caspase-independent death; necrosis; zVAD-fmk; Bcl-2; $\alpha$-toxin; DNA fragmentation

Abbreviations: FACS, fluorescence-activated cell sorter; FITC, fluorescein isothiocyanate; HMGB1, high-mobility group 1; LDH, lactate dehydrogenase; PFGE, pulsed-field gel electrophoresis;
PI, propidium iodide; TNF, tumor necrosis factor; zVAD-fmk, benzoyl-Val-Ala-Asp-fluoromethylketone

\section{Introduction}

Cells can die in two fundamental ways: by a yet ill-defined necrotic pathway following damage of their cell membrane or by a well-characterized process, called programmed cell death or apoptosis that includes the shrinkage and blebbing of the intact cell membrane. ${ }^{1}$ Necrotic cell death results from physical or chemical injury, and is accompanied by swelling of the cells and organelles, as well as by cytoplasmic vacuolation and increased permeability of the plasma membrane allowing the passive diffusion of ions. Apoptosis, on the other hand, is characterized by stereotypic biochemical and morphological changes including chromatin condensation, oligonucleosomal DNA fragmentation and formation of apoptotic bodies that can be cleared by phagocytes without producing an inflammatory response. ${ }^{1}$ Most of these alterations are due to the activation of a class of intracellular cysteine proteases, called caspases that cleave cellular substrates after aspartate residues. ${ }^{2,3}$

Apoptosis can be achieved by a variety of stimuli such as death receptors, DNA-damaging agents, cytokine withdrawal, etc., all of which efficiently activate caspases. As cell death can be blocked in many apoptotic, but not necrotic systems by caspase inhibitors, it was widely accepted that these proteases are indispensable for apoptosis, and hence activation of caspases classified a particular mode of cell death as apoptosis. However, recent reports suggest the existence of intermediate cell death forms, making it sometimes difficult to unambiguously define the mode of death a particular cell is undergoing. ${ }^{1,4}$ Perhaps, two of the first clear demonstrations of caspase-independent programmed cell death were apoptosis induced by the proapoptotic $\mathrm{Bcl}-2$ homologues $\mathrm{Bax}^{5,6}$ and Bak. ${ }^{7}$ Although cell death mediated by both molecules was accompanied by caspase activation, the inhibition of these enzymes only blocked the apoptotic morphology, but not cell death itself. More recent examples include apoptosis induced during thymocyte development, ${ }^{8}$ HIV-1 infection of primary T cells, ${ }^{9}$ stimulation of surface antigens such as CD4, CD47 and CD99, ${ }^{10-12}$ or CTLmediated target cell lysis. ${ }^{13}$ In parallel, it became evident that apoptosis can also occur in the complete absence of caspase activation. ${ }^{14,15}$ Even death receptors such as CD95 or TNF receptor-1, which were originally believed to mediate cell death exclusively via the direct activation of the caspase cascade, were shown to simultaneously activate mechanistically different death pathways leading either to necrosis or apoptosis. ${ }^{16-19}$ Thus, the presence or absence of active caspases alone does not qualify a particular cell death system as apoptosis or necrosis, respectively. In most of the abovementioned systems, however, cell death could be blocked by 
the antiapoptotic protein Bcl-2, thereby clearly distinguishing these systems from necrosis in which cell death is merely a result of the damage per se. Therefore, the term apoptosislike programmed cell death ${ }^{1}$ appears to be appropriate for death events that are under tight regulation of intracellular survival mechanisms.

Staphylococcus aureus is one of the most common grampositive bacterial pathogens that plays an increasing role in nosocomial infections such as abscess formation, osteomyelitis, endocarditis or pneumonia, which often require a prolonged and aggressive antibiotic treatment. ${ }^{20}$ Among the most serious complications of $S$. aureus infections are manifestations of septic and toxic shock syndromes that may lead to multiple organ failure. ${ }^{21}$ As tissue injury and a depletion of immune cells are characteristic features of septic and toxic shock syndromes, several studies have focused on cell death induction following exposure to microbial pathogens. $^{22,23}$ Indeed, it was shown that $S$. aureus is able to induce apoptosis in various cell types including epithelial cells, endothelial cells, keratinocytes, osteoblasts as well as lymphocytes and macrophages. ${ }^{24-29}$ One of the key virulence determinants of $S$. aureus is $\alpha$-toxin, a pore-forming protein of $34 \mathrm{kDa}$. At low doses, the toxin was shown to bind to specific, as yet unidentified cell surface receptors, and to produce small heptameric pores that selectively facilitate the release of monovalent ions, resulting in DNA fragmentation and apoptosis. ${ }^{24,30,31}$ At high doses $(>6 \mu \mathrm{g} / \mathrm{ml})$, in contrast, $\alpha$-toxin nonspecifically adsorbs to the lipid bilayer, forming larger pores that are $\mathrm{Ca}^{2+}$-permissive, which results in massive necrosis. In addition, we have recently demonstrated that only low $\alpha$-toxin doses activate caspases, and that this activation is mediated via the intrinsic pathway independently of death receptors. $^{32}$ Thus, it appears that the mode of cell death critically depends on the concentration of $\alpha$-toxin.

However, as discussed above, both oligonucleosomal DNA fragmentation and caspase activation are not necessarily required for apoptotic processes. Therefore, we analyzed this system in more detail, resulting in some intriguing findings that challenge the current concept of cell death induced by $\alpha$-toxin. Using various methods for cell death assessment, we found that inhibition of caspases did not protect cells from $\alpha$-toxininduced death. Moreover, and most interestingly, our results suggest that even in the presence of active caspases $\alpha$-toxin induces cell death via a necrotic pathway. Thus, our findings are in sharp contrast to numerous death models in which the caspase-independent mode of cell death only surfaces when the activation of caspases is inhibited, and therefore indicate that inhibition of caspases might not be sufficient to prevent the demise of $S$. aureus-infected cells.

\section{Results}

\section{Caspase inhibition by zVAD-fmk only partially prevents $S$. aureus $\alpha$-toxin-induced DNA fragmentation}

Recently, we demonstrated that $\alpha$-toxin, a major hemolysin of $S$. aureus, induces caspase activation via the mitochondrial pathway independently of death receptor signaling. ${ }^{32}$ During this work, however, we also noticed that although $S$. aureus- induced caspase activation was almost completely blocked in $\mathrm{Bcl}-2-$ overexpressing Jurkat cells, the formation of hypodiploid nuclei as measured by FACS analysis could only be partially prevented in these cells. These results indicated that caspases might not be required for $S$. aureus-induced DNA fragmentation and cell death. To investigate this hypothesis in more detail, we first analyzed hypodiploid nuclei formation induced by either $\alpha$-toxin or by a supernatant of the cytotoxic $S$. aureus strain Wood 46 in the absence or presence of the broad spectrum caspase inhibitor zVAD-fmk. Similar to the results obtained with Jurkat $\mathrm{Bcl}-2$ cells, ${ }^{32}$ caspase inhibition by $z V A D$-fmk resulted in only a partial decrease of $S$. aureusinduced DNA fragmentation (Figure 1a). Even with the lowest Wood 46 or $\alpha$-toxin concentrations that efficiently induced
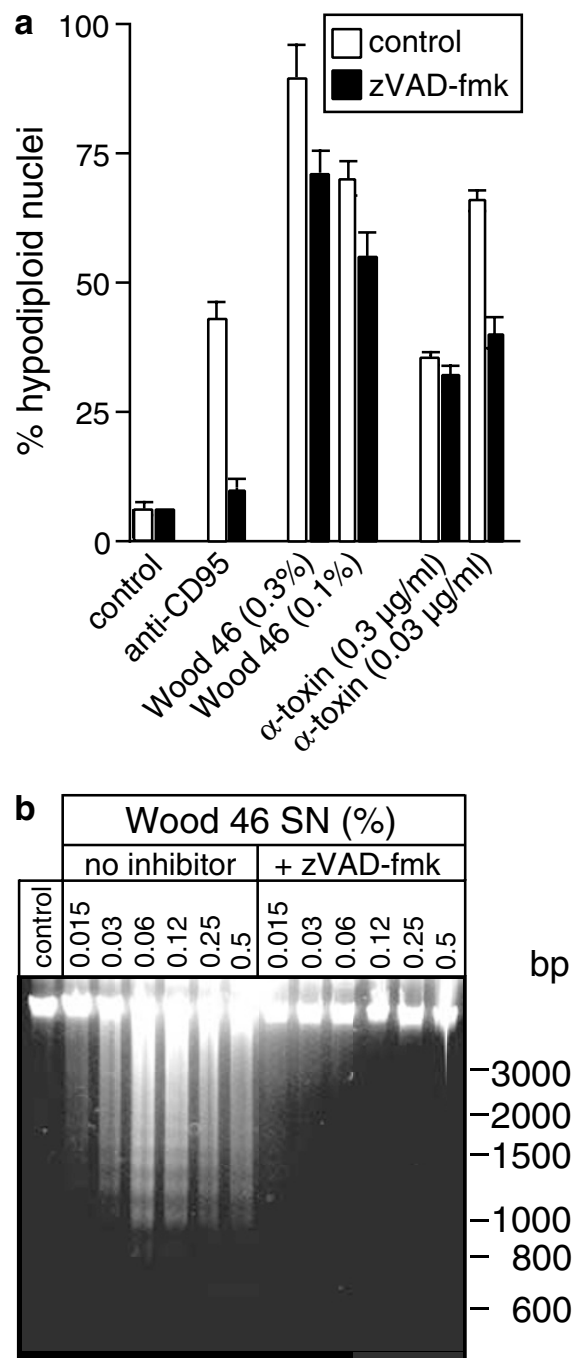

Figure $1 \alpha$-toxin-induced DNA fragmentation is only partially prevented by zVAD-fmk. Jurkat cells were either left untreated (control) or incubated with antiCD95, or with supernatant (SN) of the cytotoxic S. aureus strain Wood 46 or with purified $\alpha$-toxin at the indicated concentrations in the absence or presence of zVAD-fmk. The proportion of hypodiploid nuclei (a) and internucleosomal DNA fragmentation (b) were determined by flow cytometric analysis (a) after $24 \mathrm{~h}$ and by CAGE (b) after $6 \mathrm{~h}$, respectively. In (a), one representative experiment out of three is shown. In (b), the positions of the DNA molecular size marker are indicated to the right 
caspase-3 activation (Figure 2; Bantel et al. ${ }^{32}$ ), zVAD-fmk reduced hypodiploid nuclei formation by only 22 and $40 \%$, respectively. In contrast, CD95-induced DNA fragmentation in Jurkat cells was almost completely blocked in the presence of zVAD-fmk (Figure 1a). Interestingly, although $S$. aureusinduced formation of hypodiploid nuclei was only partially inhibited by zVAD-fmk, internucleosomal DNA fragmentation in Jurkat cells treated with various concentrations of the $S$. aureus strain Wood 46 was completely abrogated in the presence of this caspase inhibitor (Figure 1b). Thus, our results indicate that $S$. aureus $\alpha$-toxin induces DNA fragmentation in a caspase-dependent and -independent manner.

\section{Caspase inhibition by zVAD-fmk or overexpression of $\mathrm{Bcl}-2$ does not prevent $\alpha$-toxin-induced cell death}

To verify these results in another experimental setting, we analyzed the effect of zVAD-fmk on $\alpha$-toxin-induced caspase3 activation, the caspase responsible for internucleosomal DNA fragmentation during apoptosis. ${ }^{33}$ The neutralizing anti$\alpha$-toxin antibody was included as a control. ${ }^{32}$ As expected, the addition of ZVAD-fmk completely abolished $\alpha$-toxin- and Wood 46-induced caspase-3 activation, as demonstrated by Western blot analysis (Figure 2a) and by the fluorogenic substrate assay, respectively (Figure $2 b$ and $d$ ). Caspase- 3 activation was also efficiently blocked by the anti- $\alpha$-toxin antibody when low $\alpha$-toxin $(<0.1 \mu \mathrm{g} / \mathrm{ml})$ or Wood $46(<0.5 \%)$ concentrations were used, whereas higher $\alpha$-toxin or Wood 46 doses resulted in a partial activation of caspase-3 (Figure 2a, b and d). Both zVAD-fmk and anti- $\alpha$-toxin also prevented the activation of the initiator caspases 8 and 9 (data not shown). CD95-induced caspase-3 activation, in contrast, was only blocked by zVADfmk, but not by the anti- $\alpha$-toxin antibody, demonstrating the specificity of this antibody (Figure 2a).

Remarkably, although both zVAD-fmk and the anti- $\alpha$-toxin antibody efficiently blocked $\alpha$-toxin- and Wood 46-mediated caspase activation, cell death was dose-dependently inhibited only by the anti- $\alpha$-toxin antibody but not by zVAD-fmk, as determined by the trypan blue exclusion assay (Figure $2 c$ and e). It is noteworthy that zVAD-fmk also had no effect on the progression of cell death, even when low $\alpha$-toxin or Wood 46 doses that are known to efficiently activate caspase-3 were used. Therefore, these results indicate that caspases are dispensable for $S$. aureus-mediated cell death.

Next, we compared cell death and DNA fragmentation in Jurkat and Jurkat $\mathrm{Bcl}-2$ cells treated with $\alpha$-toxin in the presence or absence of zVAD-fmk. Consistent with our previous results (Figure 1a), we observed that $\alpha$-toxin induced two different DNA fragmentation events in Jurkat cells, which could be easily distinguished based on the inhibitory potential of zVAD-fmk (Figure 3a). The zVAD-fmk-inhibitable and therefore caspase-dependent DNA fragmentation was, however, only evident when low $\alpha$-toxin concentrations ranging from 0.01 to $0.03 \mu \mathrm{g} / \mathrm{ml}$ were used. This is in agreement with our previous report that caspases are only activated when low $\alpha$-toxin doses were used. $^{32}$ Treatment of Jurkat cells with higher $\alpha$-toxin doses $(>0.03 \mu \mathrm{g} / \mathrm{ml}$ ) additionally resulted in a caspase-independent DNA fragmentation that could not be
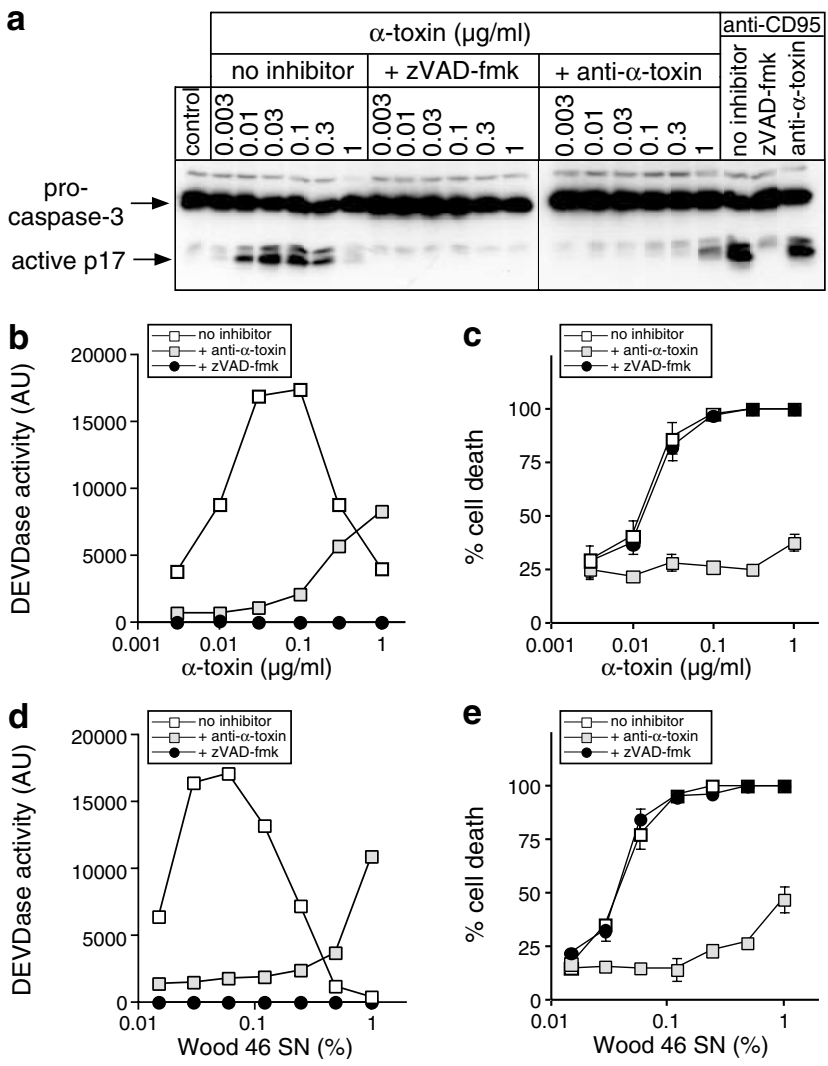

Figure 2 zVAD-fmk completely abrogates $\alpha$-toxin-induced caspase- 3 activation, but not cell death. (a) Western blot analysis demonstrating the status of caspase-3 in Jurkat cells that were either left untreated (control) or incubated for $4 \mathrm{~h}$ with the indicated concentrations of $\alpha$-toxin in the absence or presence of zVAD-fmk or the anti- $\alpha$-toxin antibody. As a control, Jurkat cells were also incubated for $4 \mathrm{~h}$ with anti-CD95 in the absence or presence of zVAD-fmk or the anti- $\alpha$-toxin antibody. The caspase- 3 proform and the active p17 subunit are indicated. (b, d) DEVDase activity in extracts of Jurkat cells incubated for $4 \mathrm{~h}$ with the indicated concentrations of $\alpha$-toxin (b) or Wood 46 supernatant (SN) (d) in the absence or presence of ZVAD-fmk or the anti- $\alpha$-toxin antibody. One representative experiment out of six performed in triplicates is shown. (c, e) Assessment of cell death by trypan-blue uptake of Jurkat cells incubated for $4 \mathrm{~h}$ with the indicated concentrations of $\alpha$-toxin (c) or Wood 46 supernatant (SN) (e) in the absence or presence of zVAD-fmk or the anti- $\alpha$-toxin antibody. One representative experiment out of six performed in triplicates is shown

blocked by zVAD-fmk (Figure 3a). In Jurkat Bcl-2 cells, however, $\alpha$-toxin induced only a caspase-independent DNA fragmentation (Figure $3 b$ ), which is consistent with our previous finding that $\alpha$-toxin is unable to induce caspase activation in these cells. ${ }^{32}$ In contrast to zVAD-fmk, the anti- $\alpha$ toxin antibody completely blocked both caspase-dependent and -independent DNA fragmentation, demonstrating that both processes were indeed mediated by $\alpha$-toxin (Figure 3a and b). As a control, induction of apoptosis in Jurkat and Jurkat Bcl-2 cells by either anti-CD95 or the anti-cancer drug etoposide resulted exclusively in caspase-dependent DNA fragmentation, as it could be completely blocked by zVAD-fmk but not by the anti- $\alpha$-toxin antibody (Figure $3 a$ and $b$ inlets).

To analyze whether the caspase-dependent apoptotic pathway contributes to cell death induced by $\alpha$-toxin, we employed an FACS-based method using propidium iodide 

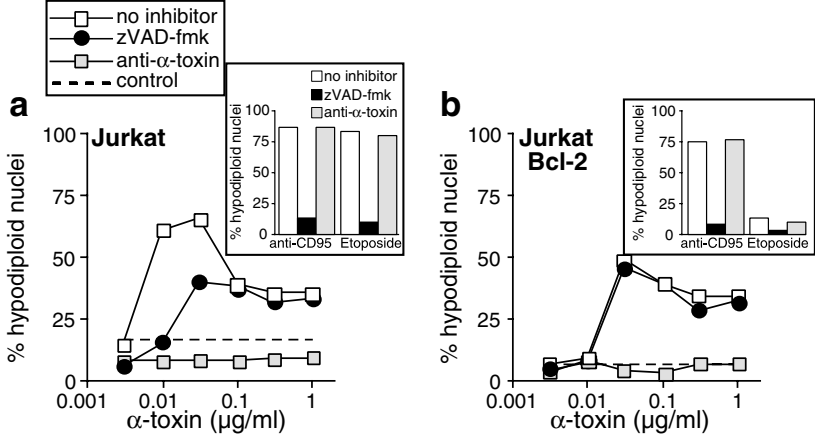

c

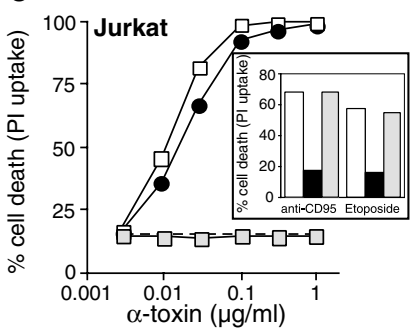

d
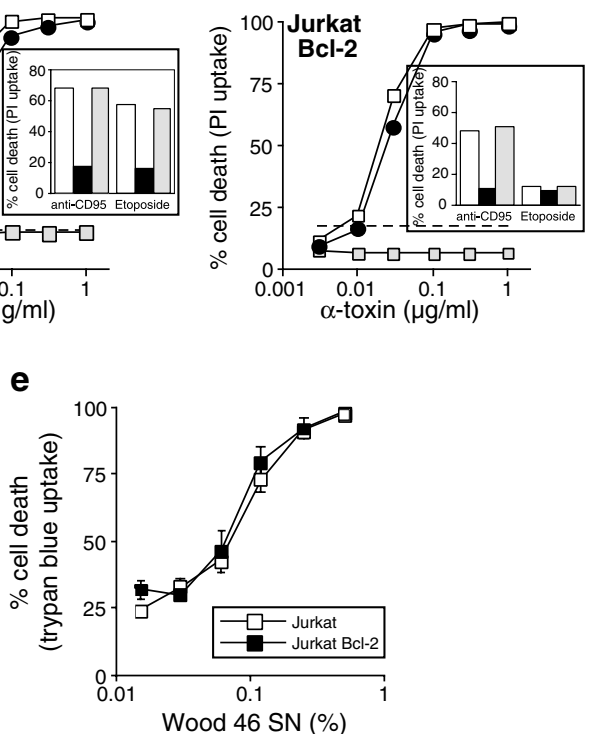

Figure $3 \alpha$-toxin induces caspase-dependent and -independent DNA fragmentation. Jurkat (a) and Jurkat Bcl-2 cells (b) were incubated at $37^{\circ} \mathrm{C}$ with the indicated concentrations of $\alpha$-toxin in the absence or presence of ZVADfmk or the anti- $\alpha$-toxin antibody. As a control, both cell lines were also incubated with anti-CD95 or etoposide in the absence or presence of ZVAD-fmk or the anti$\alpha$-toxin antibody (inlets of $(\mathbf{a}, \mathbf{b})$ ). The proportion of hypodiploid nuclei was determined by flow cytometric analysis after $24 \mathrm{~h}$. (c, d) Cell death assessment of Jurkat (c) and Jurkat Bcl-2 cells (d) treated as above. Cell death was determined after $24 \mathrm{~h}$ by flow cytometric analysis based on the uptake of PI. (e) Assessment of cell death by trypan-blue uptake of Jurkat and Jurkat Bcl-2 cells incubated for $4 \mathrm{~h}$ with the indicated dilutions of Wood 46 supernatant (SN). One representative experiment out of three is shown

(PI)-stained cells. This assay system allows determination of the total percentage of cell death, regardless of whether the cells died via an apoptotic or necrotic pathway. Using this method, we could demonstrate that ZVAD-fmk had no effect on $\alpha$-toxin-mediated killing of Jurkat and Jurkat Bcl-2 cells, whereas CD95- or etoposide-induced death were significantly blocked by this caspase inhibitory peptide (Figure 3c, d). Even with $\alpha$-toxin concentrations ranging from 0.01 to $0.1 \mu \mathrm{g} / \mathrm{ml}$ that efficiently induced caspase activation (Figure $2 \mathrm{a}$ ) and hence were expected to mediate apoptosis, zVAD-fmk was not able to diminish Jurkat cell death. In contrast, anti- $\alpha$-toxin completely blocked $\alpha$-toxin-induced death of both cell lines, but had no effect on CD95- or etoposide-induced apoptosis (Figure $3 \mathrm{c}, \mathrm{d}$ ). In addition, cell death assessment by the trypan blue exclusion assay confirmed these results and revealed no differences in the susceptibility of both Jurkat cell lines to the cytotoxic activity of $S$. aureus Wood 46 supernatant (Figure 3e). Together, these results demonstrate that although $S$. aureus $\alpha$-toxin efficiently induces caspase activation, cell death induced by this pathogen proceeds most likely in a caspase-independent manner.

\section{S. aureus $\alpha$-toxin induces caspase-independent high molecular weight DNA fragmentation}

As zVAD-fmk completely blocked $\alpha$-toxin-induced internucleosomal DNA fragmentation, but only partially prevented the formation of hypodiploid nuclei (Figure 1), we assessed the possibility of high molecular weight DNA breaks induced by this toxin. For this purpose, DNA from Jurkat cells treated for $4 \mathrm{~h}$ with various concentrations of $\alpha$-toxin in the absence or presence of zVAD-fmk or the anti- $\alpha$-toxin antibody was analyzed by pulsed field gel electrophoresis. Compared to untreated cells, all concentrations of $\alpha$-toxin markedly induced high molecular weight DNA breaks in Jurkat cells, ranging from approximately 700 to $50 \mathrm{~kb}$ in size (Figure $4 \mathrm{a}$, lanes 2-5). Remarkably, even at an $\alpha$-toxin concentration of $3 \mathrm{ng} / \mathrm{ml}$ that did not induce caspase activation (Figure 2), a high molecular weight DNA fragmentation that was efficiently blocked by the anti- $\alpha$-toxin antibody was observed (Figure $4 a$, lanes 10-13), but not by zVAD-fmk (Figure 4a, lanes 6-9). In contrast, zVAD-fmk significantly increased the accumulation of $\alpha$-toxininduced high molecular weight DNA fragments, most likely caused by the inhibition of caspases required for the further degradation of the DNA into oligonucleosomal fragments.

A similar phenomenon was also observed when DNA from anti-CD95-treated Jurkat cells was analyzed. In this case, we could not detect any high molecular weight DNA fragmentation (Figure 4a, lane 14), because at this time point most of the DNA was already cleaved into the internucleosomal fragments (data not shown), and almost no intact DNA remained in the gel slot. Although the addition of zVAD-fmk completely prevented anti-CD95-induced internucleosomal DNA fragmentation (data not shown), it also resulted in the appearance of the 700 and $50 \mathrm{~kb}$ DNA fragments (Figure $4 \mathrm{a}$, lane 15). These results indicate that also during CD95-induced apoptosis, signals that lead to caspase-dependent andindependent DNA fragmentation are generated. In contrast, $\mathrm{H}_{2} \mathrm{O}_{2}$-induced DNA fragmentation appears to proceed solely via a caspase-independent pathway, as zVAD-fmk did not change the pattern of high molecular weight DNA breaks (Figure 4a, compare lanes 16 and 17).

In addition to $\alpha$-toxin, $S$. aureus also secretes a nuclease. To investigate whether our $\alpha$-toxin preparation or the cytotoxic supernatant of $S$. aureus cultures exhibit intrinsic DNA fragmentation activity, we analyzed DNA isolated from untreated Jurkat cells, which was incubated with various concentrations of $\alpha$-toxin or Wood 46 supernatant by pulsed field and by conventional gel electrophoresis. As shown in Figure 4b, DNA was only excessively fragmented by DNase I, but remained fully intact even in the presence of high $\alpha$-toxin or Wood 46 concentrations. Thus, we conclude that $\alpha$-toxin- and Wood 46-induced DNA fragmentation is not mediated by a contaminating nuclease, but most likely by activation of an as yet unknown intracellular caspase-independent DNase. 


\section{S. aureus $\alpha$-toxin mediates cell death via a necrotic pathway}

So far, all experiments performed point to a caspaseindependent cell death induced by $\alpha$-toxin. To verify these results in other experimental settings, we also assessed cell death by alternative methods. First, we measured the release of lactate dehydrogenase (LDH), an event that appears to be

a

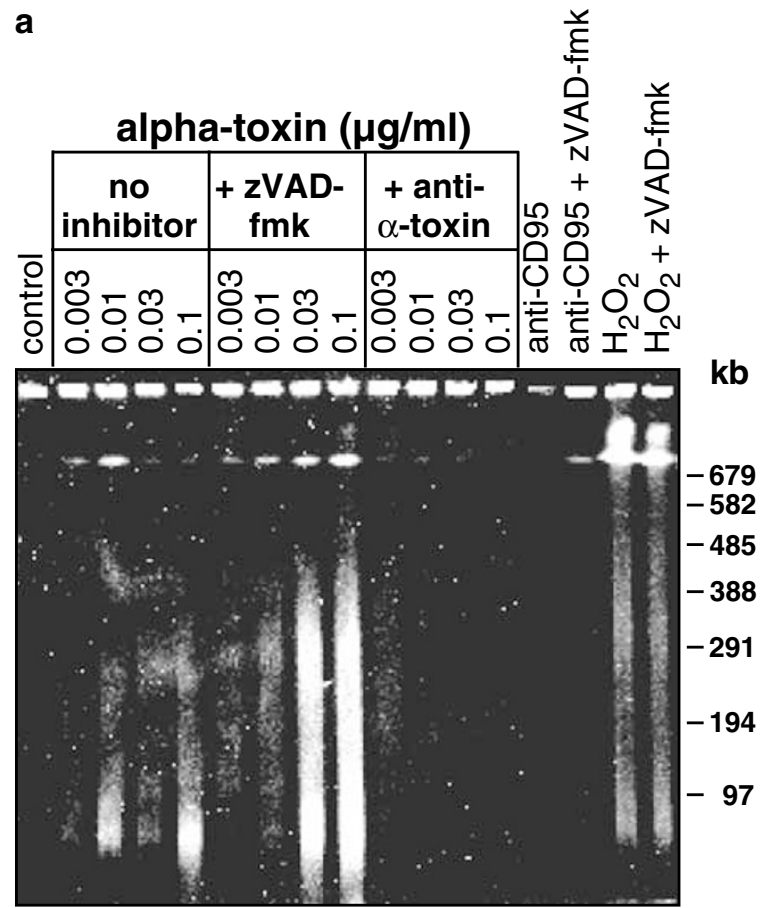

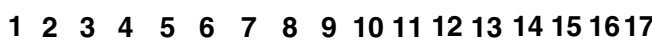

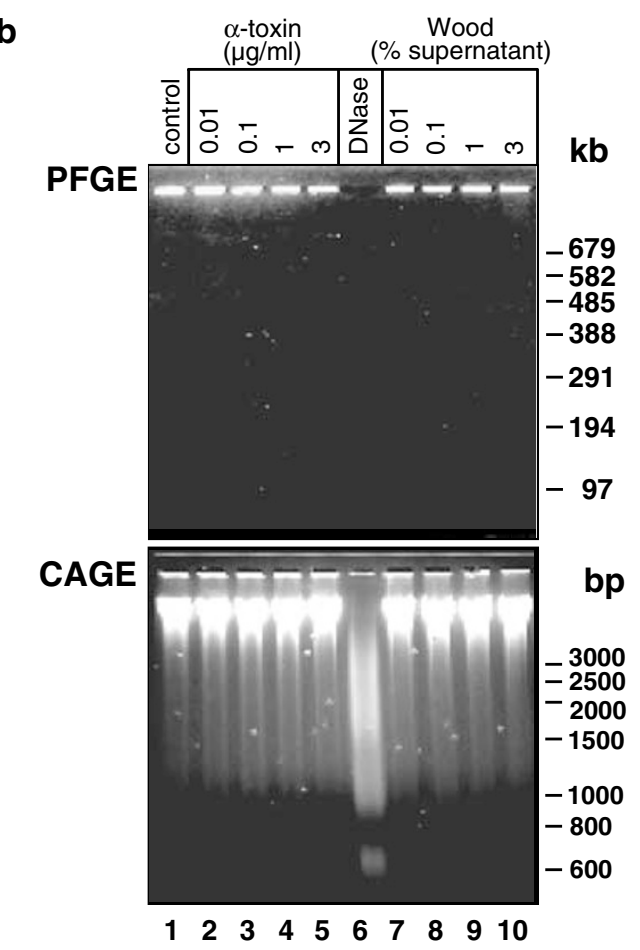

b more closely associated with necrosis than apoptosis. Consistent with this, we observed a dramatic increase of LDH activity in supernatants of Jurkat and Jurkat Bcl-2 cells incubated with $\mathrm{H}_{2} \mathrm{O}_{2}$, a typical inducer of necrosis, whereas treatment of the cells with the apoptotic inducer CD95 did not result in a significant release of this enzyme (Figure $5 b, d$ ). In
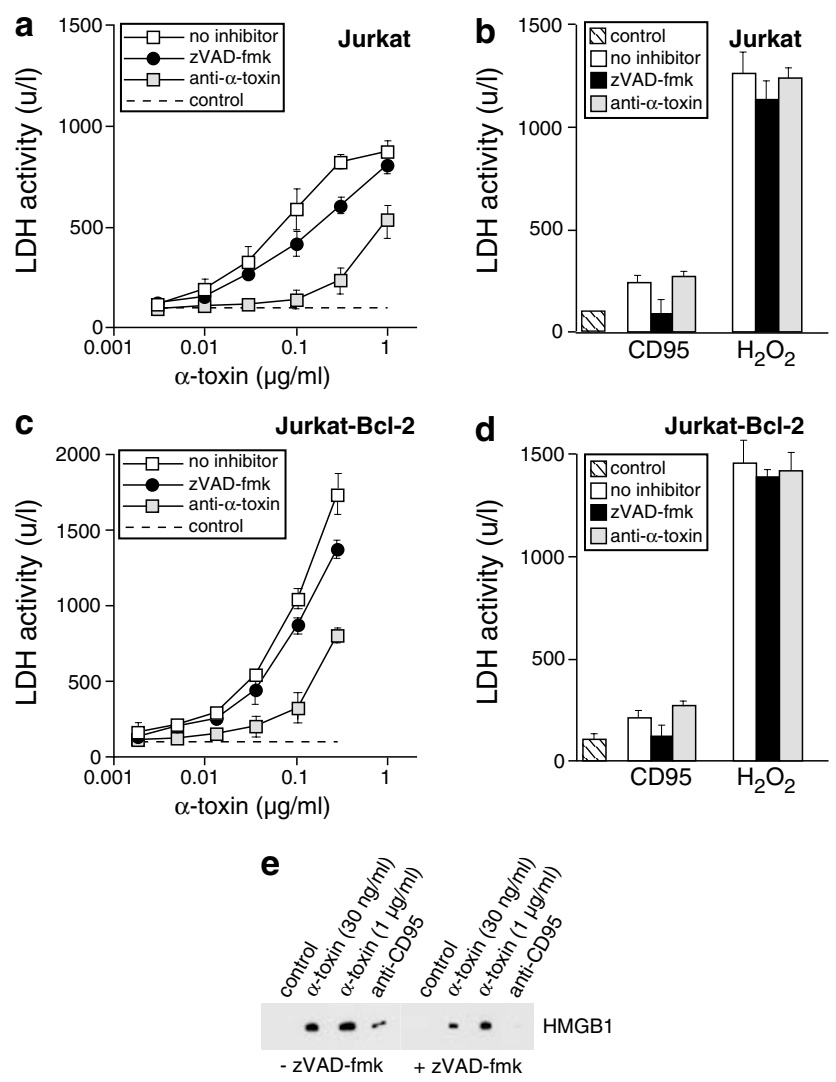

Figure $5 \alpha$-toxin induces the release of LDH and HMGB1 independently of caspases. (a, c) Measurement of LDH release in supernatants of Jurkat (a) and Jurkat Bcl-2 cells (c) that were incubated for $4 \mathrm{~h}$ with the indicated concentrations of $\alpha$-toxin in the absence or presence of ZVAD-fmk or the anti- $\alpha$-toxin antibody. (b, d) Supernatants of both cell lines were also analyzed for $\mathrm{LDH}$ activity following treatment with anti-CD95 or $\mathrm{H}_{2} \mathrm{O}_{2}$ in the absence or presence of $\mathrm{ZVAD}$-fmk or the anti- $\alpha$-toxin antibody. One representative experiment out of three is shown. (e) Jurkat cells were either treated with low $(30 \mathrm{ng} / \mathrm{ml})$ or high $(1 \mu \mathrm{g} / \mathrm{ml}) \alpha$-toxin concentrations or with anti-CD95 $(500 \mathrm{ng} / \mathrm{ml})$ in the absence or presence of zVAD-fmk. After $16 \mathrm{~h}$, cells were pelleted at $1200 \mathrm{rpm}$, and the supernatants were analyzed for the release of HMGB1 by Western blotting

Figure $4 \alpha$-toxin induces high molecular DNA fragmentation. (a) Jurkat cells were either left untreated (control) or incubated for $2 \mathrm{~h}$ with the indicated concentrations of $\alpha$-toxin in the absence (lanes 2-5) or presence of ZVAD-fmk (lanes 6-9) or the anti- $\alpha$-toxin antibody (lanes 10-13). Cells were also treated for $2 \mathrm{~h}$ with anti-CD95 (lane 14 and 15) or $\mathrm{H}_{2} \mathrm{O}_{2}$ (lane 16 and 17) in the absence or presence of zVAD-fmk. High molecular weight DNA fragmentation was determined by PFGE. The positions of the DNA molecular size marker are indicated on the right. (b) $\alpha$-toxin or Wood-46 supernatants do not exhibit intrinsic DNase activity. Isolated DNA from untreated Jurkat cells was either left untreated (control), or incubated for $2 \mathrm{~h}$ at $37^{\circ} \mathrm{C}$ with the indicated concentrations of $\alpha$-toxin or Wood 46 supernatant. As a control, DNA was incubated with DNasel (400 U/ $\mathrm{ml}$ ). High molecular weight and internucleosomal DNA fragmentation were determined by PFGE (top) and CAGE (bottom), respectively. The positions of the DNA molecular size markers are indicated on the right 
addition, the caspase inhibitor zVAD-fmk had only a marginal effect on $\mathrm{LDH}$ release induced by both death stimuli, implying that this assay might be suitable to distinguish necrotic from apoptotic forms of cell death.

When Jurkat or Jurkat Bcl-2 cells were incubated with the indicated concentrations of $\alpha$-toxin, a dose-dependent increase in LDH activity was observed in their supernatants (Figure 5a, c). Interestingly, this effect was even more pronounced in Jurkat Bcl-2 cells, a cell line in which $S$. aureus fails to induce caspase activation. ${ }^{32}$ More important, however, was our finding that $\alpha$-toxin-induced LDH release from both cell lines was only blocked in the presence of the anti- $\alpha$-toxin antibody, but not by zVAD-fmk. In agreement with our previous data (Figures 2 and 3), zVAD-fmk also had no effect even when low, caspase-activating $\alpha$-toxin concentrations were used, confirming that $\alpha$-toxin induces a caspaseindependent mode of cell death.

Recently, the high-mobility group 1 (HMGB1) protein was identified as another specific marker to distinguish necrosis from apoptosis. ${ }^{34}$ It was shown that HMGB1 is only released into the supernatant of necrotic cells, but barely in the supernatant of apoptotic cells due to its tight association with chromatin. In agreement with this report, we observed only a slight release of HMGB1 into the supernatant of Jurkat cells stimulated for $14 \mathrm{~h}$ with anti-CD95 that was completely abrogated by zVAD-fmk (Figure $5 \mathrm{e}$ ). In contrast, when the cells were treated with either $30 \mu \mathrm{g} / \mathrm{ml}$ or $1 \mu \mathrm{g} / \mathrm{ml} \alpha$-toxin, a substantial HMGB1 release could be detected, which was only marginally affected by the presence of zVAD-fmk (Figure 5e), further supporting the above drawn conclusion.

Intracellular (d)ATP is a critical coactivator of caspases required for the formation of the apoptosome in the mitochondrial death pathway. ${ }^{2}$ Hence, in caspase-dependent apoptosis systems, inhibition of caspase activation by either Bcl-2 or zVAD-fmk should maintain the intracellular ATP levels. Based on this assumption, we monitored the ATP content of anti-CD95- or $\mathrm{H}_{2} \mathrm{O}_{2}$-treated Jurkat cells, which are considered to be type II cells in which CD95-induced apoptosis is mediated also via the intrinsic death pathway. ${ }^{35}$ Indeed, anti-CD95-induced ATP depletion in Jurkat cells was completely abrogated in the presence of either zVAD-fmk or $\mathrm{Bcl}-2$, confirming our assumption (Figure $6 \mathrm{c}$ ). In contrast, both caspase inhibitors had no effect on $\mathrm{H}_{2} \mathrm{O}_{2}$-induced ATP depletion, clearly demonstrating the caspase-independent necrotic mode of cell death (Figure 6c). Therefore, measurement of the intracellular ATP content in the presence of caspase inhibitors represents an efficient assay to distinguish whether a particular cell death system requires active caspases or not.

In Jurkat cells, $\alpha$-toxin mediates caspase activation solely via the mitochondrial death pathway, independently of death receptor signaling. ${ }^{32}$ In contrast to the caspase-dependent mode of cell death instigated by anti-CD95, $\alpha$-toxin induced a dose-dependent ATP depletion in Jurkat cells that could only be blocked by anti- $\alpha$-toxin, but not by zVAD-fmk or Bcl-2 (Figures $6 \mathrm{a}$ and $\mathrm{b}$, respectively). In addition, our data reveal that also in contrast to CD95, $\alpha$-toxin induced the intracellular loss of ATP in Jurkat and in Jurkat Bcl-2 cells with a similar dose dependency. Thus, with regard to some biochemical criteria, our data demonstrate that cell death induced by
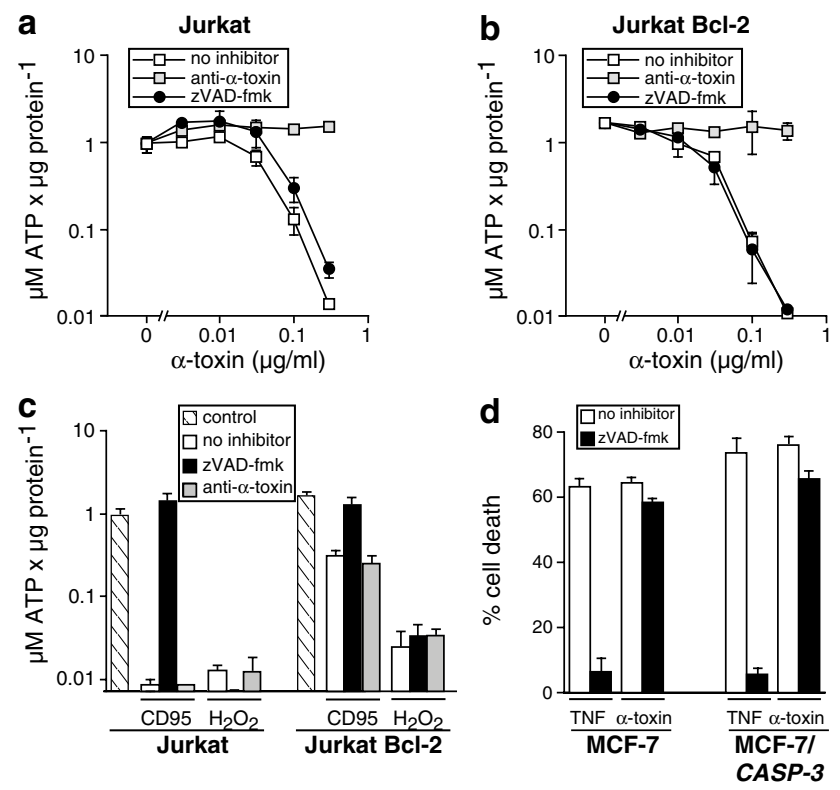

Figure $6 \quad \alpha$-toxin induces intracellular ATP depletion independently of caspases. (a, b) Determination of the intracellular ATP content present in Jurkat (a) and Jurkat Bcl-2 cells (b) following a $4 \mathrm{~h}$ exposure to the indicated concentrations of $\alpha$-toxin in the absence or presence of zVAD-fmk or the anti- $\alpha$ toxin antibody. (c) Determination of the intracellular ATP content present in Jurkat and Jurkat Bcl-2 cells following a $4 \mathrm{~h}$ exposure to anti-CD95 or $\mathrm{H}_{2} \mathrm{O}_{2}$ in the absence or presence of zVAD-fmk or the anti- $\alpha$-toxin antibody. Control bars represent the intracellular ATP content in untreated cells. One representative experiment out of three is shown. (d) $\alpha$-toxin also induces in MCF-7 cells a caspase-independent form of cell death. Determination of cell death of MCF-7 and MCF-7/CASP-3 cells treated for $16 \mathrm{~h}$ with TNF $(30 \mathrm{ng} / \mathrm{ml})$ or $\alpha$-toxin $(30 \mathrm{ng} /$ $\mathrm{ml}$ ) in the absence or presence of zVAD-fmk. Cell death was assessed by the crystal violet assay that is based on the staining of viable cells

$\alpha$-toxin resembles rather the caspase-independent necrotic death induced by $\mathrm{H}_{2} \mathrm{O}_{2}$ than that of the caspase-dependent CD95-mediated apoptotic pathway.

So far, $\alpha$-toxin-induced cell death was only assessed in Jurkat cells and with methods based on the uptake or release of small molecules through the cellular membrane. As $\alpha$-toxin is a pore-forming toxin, these measurements may not accurately reflect the nature of cell death induced by this staphylococcal toxin. Therefore, $\alpha$-toxin-induced cell death was also assessed in MCF-7 and MCF-7/CASP-3 breast carcinoma cells ${ }^{33}$ by the crystal violet assay that is based on the staining of adherent and hence viable cells. In agreement with our previous results, we found that although both cell lines were efficiently killed by TNF or $\alpha$-toxin, zVAD-fmk rescued only TNF-treated cells, but had no effect on cell death induced by $\alpha$-toxin (Figure 6d). Owing to a $47 \mathrm{bp}$ deletion in the casp-3 gene, MCF-7 cells completely lack caspase-3 protein, which is required for internucleosomal DNA fragmentation. ${ }^{33}$ However, caspase-3-deficient MCF-7 cells were killed by $\alpha$ toxin to a similar extent as caspase-3-expressing MCF-7 cells, clearly demonstrating that $\alpha$-toxin-induced death is not only independent of caspase-3, but also independent of the characteristic apoptotic events mediated by this protease. Therefore, our data indicate that $\alpha$-toxin induces a caspaseindependent necrotic death pathway. 
$\alpha$-toxin induces a necrotic form of cell death that is biochemically and morphologically distinct from apoptosis even in the presence of active caspases

Numerous studies have described caspase-independent apoptosis pathways that, however, only surface in the presence of ZVAD-fmk. ${ }^{5-7,16-19}$ Common to all these systems was the observation that $z V A D$-fmk did not prevent cell death, but changed the apoptotic morphology to a necrotic phenotype. Having clearly established that inhibition of caspases does not protect cells from $\alpha$-toxin-mediated cytotoxicity, the question still remained whether the same scenario applies to cell death induced by $\alpha$-toxin, or whether $\alpha$-toxin induces necrosis even in the presence of active caspases. In an attempt to answer this question, we first compared the cell death patterns induced by low $(30 \mathrm{ng} / \mathrm{ml})$ and high $(1 \mu \mathrm{g} / \mathrm{ml}) \alpha$ - toxin concentrations with the apoptotic mode of cell death induced by anti-CD95 using the conventional annexin V/PI double-staining technique. This method allows to follow the fate of dying cells that under typical apoptotic conditions first stain positive for annexin $\mathrm{V}$ (early apoptotic cells) and then become double positive for annexin $\mathrm{V}$ and $\mathrm{PI}$ (late apoptotic or secondary necrotic cells). Anti-CD95 induced equal proportions of single- and double-positive cells that could be completely blocked by zVAD-fmk (Figure 7). Overexpression of Bcl-2, however, only partially prevented anti-CD95-induced cell death (double-positive cells), but not the generation of single-positive annexin V-stained cells, which is consistent with the death receptor-mediated pathway. On the other hand, treatment of Jurkat cells with the low, caspase-activating dose of $\alpha$-toxin did not result in the generation of annexin $V$ singlepositive cells, but predominantly in annexin V/PI double-
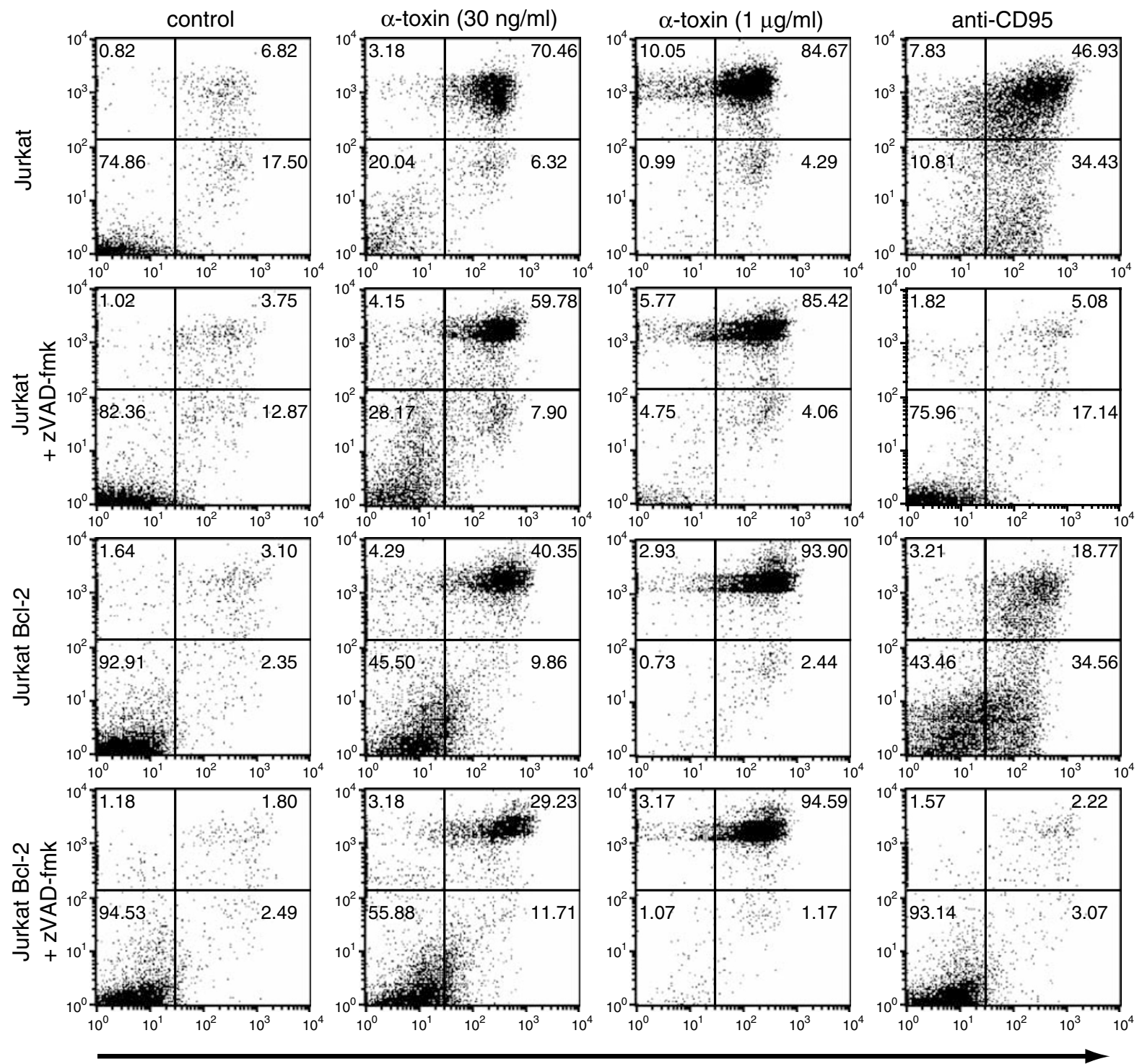

relative fluorescence intensity Annexin-FITC

Figure 7 Comparison of $\alpha$-toxin- and anti-CD95-induced cell death by annexin $\mathrm{V}$ and PI double staining. Following treatment of Jurkat cells with the indicated concentrations of anti-CD95 or $\alpha$-toxin for $14 \mathrm{~h}$, the cells were double stained with propidium iodide and the fluorescence-labeled annexin V-FITC. Cell death and caspase activation were assessed in parallel by flow cytometric analyses. One representative experiment of two performed in duplicates is shown 
positive cells, an event that was also observed at $4 \mathrm{~h}$ (data not shown). This cell population was, in contrast to anti-CD95, not substantially decreased in the presence of zVAD-fmk and only partially reduced by $\mathrm{Bcl}-2$. As expected, both means of caspase inhibition had also no effect on cell death induced by the higher $\alpha$-toxin dose of $1 \mu \mathrm{g} / \mathrm{ml}$ (Figure 7 ). Of note, however, is our observation that the high $\alpha$-toxin dose of $1 \mu \mathrm{g} / \mathrm{ml}$, which is not capable of activating caspases (Figure 2) does not only induce the uptake of $\mathrm{PI}$, but also the binding of annexin V (double-positive cells). This suggests that annexin $\mathrm{V}$ staining might be unrelated to caspases in $\alpha$-toxin-induced cell death. Together, these results provide further evidence that $\alpha$-toxin-induced cell death differs greatly from the classical apoptotic pattern induced by anti-CD95.

Next, we assessed the possible heterogeneity of $\alpha$-toxinand anti-CD95-treated Jurkat cells by double staining them with $\mathrm{PI}$, and a fluorescence-labeled pan caspase peptide, FITC-VAD-fmk, that recognizes active caspases. FACS analysis of Jurkat cells that were treated for $4 \mathrm{~h}$ with antiCD95 showed a dose-dependent increase only of FITCpositive cells, whereas the proportion of PI-stained cells (necrotic cells) was only marginally elevated over background levels (Figure 8a, upper left panel). Further dissection of the data revealed that these caspase-positive cells were single FITC-positive cells (apoptotic cells), as the $4 \mathrm{~h}$ treatment with anti-CD95 did neither result in an increase of single PI- or double (FITC/PI)-stained cells (Figure 8b, upper left panel). After a $16 \mathrm{~h}$ treatment with anti-CD95, however, both FITCand $\mathrm{PI}$-positive cells increased to the same extent (Figure 8a, lower left panel). These cells were exclusively double (FITC/ $\mathrm{PI}$ )-stained cells (Figure 8b, lower left panel), indicating a process called secondary necrosis, which is known to occur at a later stage in CD95-induced apoptosis. Thus, our results clearly demonstrate that truly apoptotic cells only display caspase activation, but are not yet permeable for PI.

When similar experiments were performed with $\alpha$-toxintreated Jurkat cells, the results differed greatly from those obtained following anti-CD95 treatment. Here, a $4 \mathrm{~h}$ treatment with $\alpha$-toxin induced a dose-dependent increase of cells positive for active caspases, which was exactly paralleled by $\mathrm{PI}$-stained cells (Figure 8a, upper right panel). The difference to the profile obtained with active caspase-3 (Figure 2 ) is most likely due to the fact that besides caspase- $3, \alpha$-toxin induces also the activation of other caspases such as caspase- $8,-9,{ }^{32}$ -6 , and -7 , which can be all detected by the FITC-VAD-fmk substrate. Nevertheless, this result is in sharp contrast to CD95-induced apoptosis, and indicates that $\alpha$-toxin-treated cells die via necrosis, despite the presence of active caspases. This assumption was further supported when the data were plotted in a manner that allows to assess the heterogeneity within the $\alpha$-toxin-treated cell population in more detail. In contrast to anti-CD95, a $4 \mathrm{~h}$ treatment with $\alpha$ toxin significantly increased the proportion of double-positive cells, whereas both single-positive cell populations even decreased after a slight initial rise (Figure $8 \mathrm{~b}$, upper right panel). Interestingly, when the cells were treated for $4 \mathrm{~h}$ with an $\alpha$-toxin concentration of $30 \mathrm{ng} / \mathrm{ml}$, all the three cell populations were present to approximately the same extent (Figure $8 b$, upper right panel), indicating not only the parallel occurrence of apoptosis and necrosis, but also confirming the
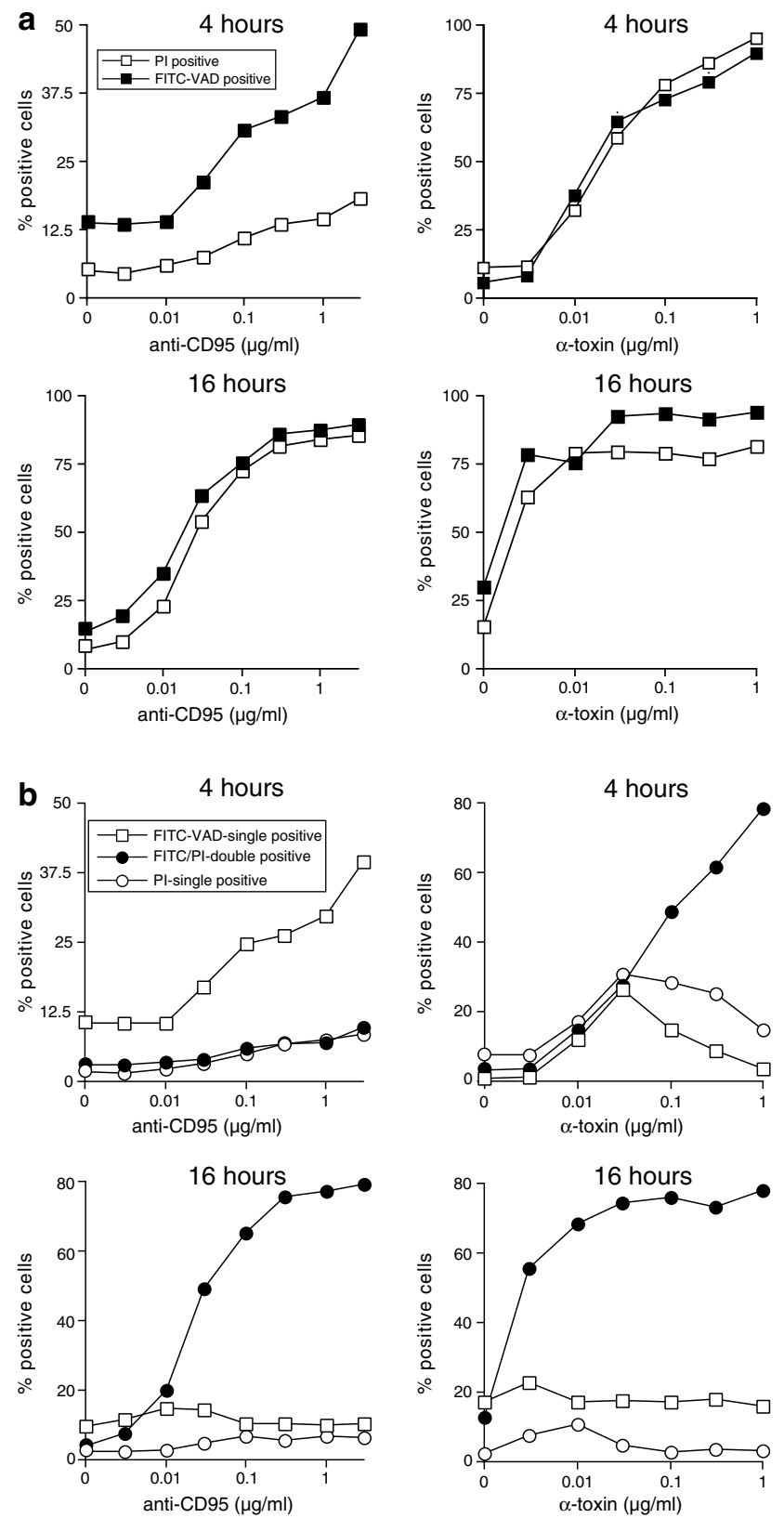

Figure $8 \alpha$-toxin induces necrosis even in the presence of active caspases. Following treatment of Jurkat cells with the indicated concentrations of anti-CD95 or $\alpha$-toxin for 4 and $16 \mathrm{~h}$, the cells were double stained with $\mathrm{PI}$ and the fluorescence-labeled pan caspase-peptide FITC-VAD-fmk. Cell death and caspase activation were assessed in parallel by flow cytometric analyses. Note that in (a) each line represents the whole population of PI- or FITC-stained cells including single- and double-positive cells, whereas in (b) the three subpopulations are plotted individually. One representative experiment of two performed in duplicates is shown

process of necrosis in the presence of active caspases. Similar results were obtained when the cells were exposed to $\alpha$-toxin for shorter times (data not shown). In contrast, a prolonged treatment for $16 \mathrm{~h}$ (Figure $8 \mathrm{~b}$, lower right panel) or higher $\alpha$-toxin doses (Figure $8 b$, right panels) yielded preferentially in the generation of double-positive cells. As 
overexpression of $\mathrm{Bcl}-2$ or cotreatment with zVAD-fmk completely abrogated $\alpha$-toxin-induced caspase activation without exhibiting a dramatic influence on the percentage of PI- and annexin V-positive cells (Figures 2, 3, 7), we conclude that caspases, although efficiently activated, are dispensible for $\alpha$-toxin-induced cell death. More importantly, our data demonstrate that $\alpha$-toxin at least partially mediates a necrotic form of cell death even in the presence of active caspases.

To confirm these findings at the ultrastructural level, we finally analyzed $\alpha$-toxin- and anti-CD95-treated Jurkat cells by electron microscopy. Anti-CD95-treated Jurkat cells showed the typical morphological characteristics of apoptotic cells such as shrinkage, chromatin condensation and fragmentation into apoptotic bodies (Figure 9a, e). As expected, all these events were completely abrogated in the presence of zVADfmk (Figure 9b, f). However, a completely different picture emerged when the cells were treated with $30 \mathrm{ng} / \mathrm{ml} \alpha$-toxin, a dose that induces not only caspase activation, but also the uptake of PI (Figures 2, 7, 8). Here we observed a swelling not
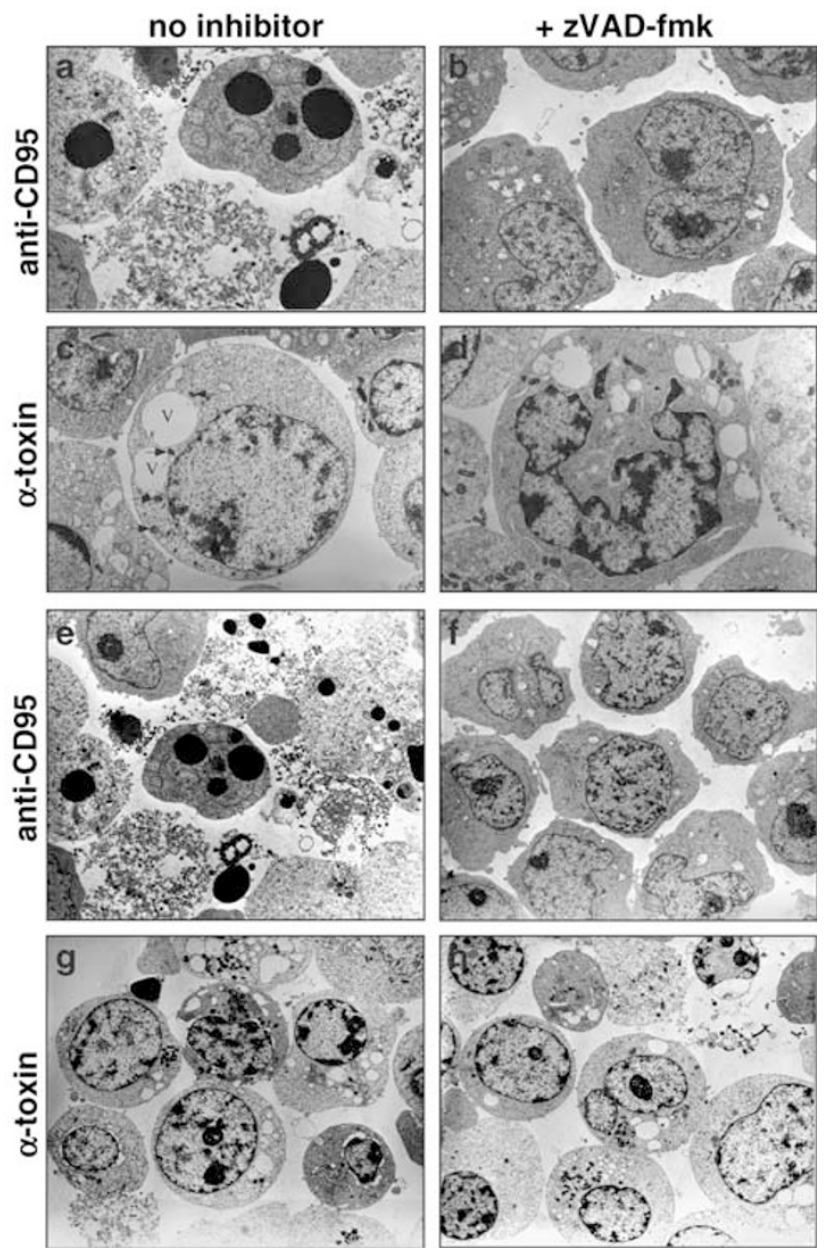

Figure $9 \alpha$-toxin induces a necrotic cell morphology even in the presence of active caspases. Ultrastructural analysis of Jurkat cells treated for $4 \mathrm{~h}$ with anti$\operatorname{CD95}(\mathbf{a}, \mathbf{b}, \mathbf{e}, \mathbf{f})$ or with $30 \mathrm{ng} / \mathrm{ml} \alpha$-toxin $(\mathbf{c}, \mathbf{d}, \mathbf{g}, \mathbf{h})$ in the absence $(\mathbf{a}, \mathbf{c}, \mathbf{e}, \mathbf{g})$ or presence $(\mathbf{b}, \mathbf{d}, \mathbf{f}, \mathbf{h})$ of ZVAD-fmk. Note that the dose of $30 \mathrm{ng} / \mathrm{ml} \alpha$-toxin efficiently induces the activation of caspase-3 as shown in Figure 2. In (c), condensed mitochondria are marked by an arrow and vacuoles by a $\mathrm{V}$ (magnification, $\times 2600$ ) only of the cytoplasm, but also of the nucleus and nuclear envelope (Figure 9c). In addition, excessive cytoplasmic vacuolation was visible, resembling a necrotic morphology. Moreover, the chromatin of $\alpha$-toxin-treated cells was only partially condensed, whereas the mitochondria appeared extremely electron dense. As expected, inhibition of caspases by zVAD-fmk did not prevent these events and, most importantly, these cells appeared with a similar morphology as those treated with $\alpha$-toxin alone (Figure 9d). The phenomenon that $\alpha$-toxin-treated Jurkat cells displayed prominent necrotic features (swelling of the nucleus, vacuolization) in the presence or absence of active caspases was observed throughout the entire preparations (Figure 9g, h). Thus, our data reveal that caspase activation does not necessarily lead to an apoptotic mode of cell death.

\section{Discussion}

$\alpha$-toxin, the major hemolysin of $S$. aureus, is a pore-forming protein, which was shown to evoke the typical apoptotic alterations such as oligonucleosomal DNA fragmentation and caspase activation in a variety of cell types. ${ }^{24,25,32}$ Previously, we have demonstrated that $\alpha$-toxin is a mediator of $S$. aureusinduced cell death, and that it activates caspases via the mitochondrial pathway. ${ }^{32}$ Caspase activation and subsequent apoptotic alterations such as oligonucleosomal DNA fragmentation and substrate cleavage were, however, only observed with low $(<300 \mathrm{ng} / \mathrm{ml}) \alpha$-toxin doses. These findings are consistent with the current concept of $\alpha$-toxin-induced cell death that only low $\alpha$-toxin doses induce apoptosis, whereas treatment with higher doses results in massive necrosis. ${ }^{24,30,31}$ Therefore, it was postulated that the mode of cell death might critically depend on the concentration of $\alpha$-toxin.

This view, however, is now being challenged by our present study, showing that low $\alpha$-toxin concentrations also induce, at least partially, a necrotic form of cell death even in the presence of activated caspases. This could be readily demonstrated in various cell death assays including the microscopic assessment of trypan blue-stained cells or in FACS analyses based on the uptake of PI into dead cells. Although caspase activation and subsequent apoptotic alterations such as oligonucleosomal DNA fragmentation and substrate cleavage in $\alpha$-toxin-treated Jurkat cells were completely blocked by the broad-spectrum caspase-inhibitory peptide zVAD-fmk or by overexpression of Bcl-2, they could not prevent final cell death. Similar results were obtained by measuring the release of LDH and HMGB1 in cell supernatants. Regardless of whether caspases were inhibited or not, LDH activity and HMGB1 protein were predominantly detected in supernatants of $\alpha$-toxin-treated cells, but barely in supernatants of apoptotic CD95-treated cells. Although it was recently shown that $\mathrm{LDH}$ can be also released by late apoptotic cells, ${ }^{34}$ together our data suggest that, at all concentrations tested, $\alpha$-toxin induces a necrotic rather than an apoptotic form of cell death. Furthermore, in contrast to the CD95-induced ATP depletion that was clearly dependent on the activation of caspases, caspase inhibition had no effect on the loss of intracellular ATP levels observed in $\alpha$-toxin-treated Jurkat cells. As ATP is required for most apoptotic 
processes, ${ }^{17,36}$ the caspase-independent loss of ATP also explains the inability of high $\alpha$-toxin doses $(>300 \mathrm{ng} / \mathrm{ml})$ to activate caspase-3. Interestingly, in all assays performed, we did not detect any significant differences in the dose- and time (data not shown)-dependent $\alpha$-toxin-induced cell death rates in the presence or absence of zVAD-fmk or Bcl-2. These results clearly demonstrate that caspases are not required for $\alpha$-toxin-induced cell death and, furthermore, suggest that cell death may proceed even in the presence of active caspases independently of them.

As all these measurements are based on either the release or uptake of molecules through the cellular membrane, one could argue that they might not be adequate assessments of cell death induced by a pore-forming toxin. However, in contrast to TNF, $\alpha$-toxin-induced death of MCF-7 breast carcinoma cells could not be blocked by zVAD-fmk, as assessed by the crystal violet assay that is based on the staining of viable adherent cells independently of pore formation. Importantly, $\alpha$-toxin induced similar cell death rates in caspase-3-deficient and -proficient MCF-7 cells, clearly demonstrating that even low $\alpha$-toxin concentrations induce cell death in a caspase-3-independent manner.

Caspase-independent apoptosis was recently observed in a variety of in vitro systems, including that induced by Baxrelated proteins, ${ }^{5-7}$ oncogenes and DNA-damaging agents, ${ }^{7}$ and even death receptors. ${ }^{16-19}$ In addition, caspase-independent death pathways also appear to be involved in the negative selection of lymphocytes, ${ }^{8,37}$ and the embryonic removal of interdigital webs. ${ }^{38}$ Caspase inhibition by zVADfmk efficiently blocked the typical apoptotic alterations in all of these systems, but could not prevent cell death itself. Instead, addition of ZVAD-fmk changed the phenotype of the dying cell from the apoptotic into the necrotic morphology. As cell death, however, could be completely blocked by Bcl-2, and hence is under the tight control of an intrinsic survival program, they are considered as apoptosis-like programmed cell deaths. ${ }^{1}$ This is in sharp contrast to cell death induced by $\alpha$-toxin. Firstly, $\alpha$ toxin-induced cell death is not inhibitable by Bcl-2. Secondly, $\alpha$-toxin concentrations up to $30 \mathrm{ng} / \mathrm{ml}$ induced an equal mixture of single caspase- and PI-positive cells as well as double-positive cells after $4 \mathrm{~h}$, and the latter cell population was even further increased when higher $\alpha$-toxin doses were applied. In contrast, CD95-induced apoptosis resulted after $4 \mathrm{~h}$ exclusively in the generation of single caspase-positive cells that were not yet permeable for $\mathrm{PI}$, demonstrating that at least early apoptosis is solely characterized by caspase activation and not by membrane damage. However, it should be noted that FITC-VAD-fmk might also detect other proteases than caspases. Finally, and most importantly, ultrastructural analysis revealed that even Jurkat cells treated with low $\alpha$-toxin doses $(30 \mathrm{ng} / \mathrm{ml})$ in the absence of caspase inhibitors displayed a prominent necrotic phenotype, characterized by swelling of the cytoplasm and nuclei as well as by cytoplasmic vacuolation. These intriguing observations demonstrate that $\alpha$-toxin induces predominantly a necrotic form of cell death even in the presence of active caspases, which is unlike other caspase-independent apoptosis systems not under the control of an intrinsic survival program.

Why are caspases then activated so efficiently by $S$. aureus $\alpha$-toxin? The answer might lie in the molecular properties of $\alpha$-toxin itself. Insertion of $\alpha$-toxin into the plasma membrane and subsequent pore formation will lead to $\mathrm{K}^{+}$efflux and $\mathrm{Na}^{+}$ influx. ${ }^{24,30,31}$ Potassium efflux has been described as an important event in the progression of apoptosis, ${ }^{39}$ and prevention of this efflux was shown to inhibit death receptorand chemical-induced apoptosis. ${ }^{40,41}$ Potassium depletion may even be required for apoptosis, since normal intracellular $\mathrm{K}^{+}$concentrations inhibited caspase activation and DNA fragmentation, ${ }^{42}$ whereas the depletion of potassium ions with depolarizing drugs was shown to cause caspase activation. ${ }^{43}$ Therefore, caspase activation by $\alpha$-toxin might be only a side effect caused by the pore-forming properties of this molecule.

Treatment of Jurkat cells with $\alpha$-toxin resulted in both oligonucleosomal and high molecular weight DNA fragmentation, and only the former event could be inhibited by zVADfmk. This is consistent with the caspase-3-dependent activation of ICAD/DFF45 that is necessary for the apoptosisspecific oligonucleosomal DNA fragmentation. ${ }^{44,45}$ As neither the $\alpha$-toxin preparation nor supernatants of the cytotoxic $S$. aureus strain Wood 46 exhibited any intrinsic DNase activity, it is likely that $\alpha$-toxin induces an as yet unknown factor that mediates high molecular weight DNA fragmentation. One possible candidate might be the recently identified apoptosisinducing factor (AIF). Upon treatment of cells with various stimuli, AIF was shown to be released from the mitochondria and to translocate to the nucleus, where it mediates via an as yet unknown factor high molecular weight DNA fragmentation. ${ }^{46}$ Indeed, a similar scenario was described in cell death induced by $S$. pneumoniae which is also not inhibitable by zVAD-fmk. ${ }^{47}$ In this study, exposure of microglia or neurons to live pneumococci caused the mitochondrial release of AIF and high molecular weight DNA fragmentation, which was blocked by microinjection of AIF-specific antiserum. As $\alpha$-toxin can directly target mitochondria leading to cytochrome $c$ release, ${ }^{32}$ one might speculate that $\alpha$-toxin-induced AIF translocation might be particularly important in those cell types, in which cell death induction may require internalization of $S$. aureus. ${ }^{25-28}$

In view of the fact that AIF does not exhibit intrinsic DNase activity, the downstream effectors remain obscure. Although several noncaspase proteases such as calpains, serine proteases and cathepsins have been implicated in cell death processes, ${ }^{4-51}$ and even the loading of any type of protease into cells provoked apoptosis-like morphologies, ${ }^{52}$ it is presently unknown whether any of these proteases are involved in $\alpha$-toxin-induced cell death. Nevertheless, the results presented here suggest that $S$. aureus $\alpha$-toxin induces cell death independently of caspases. In addition, we provide strong evidence that this cell death proceeds via the necrotic pathway even in the presence of active caspases. On first glance, our previous report ${ }^{32}$ and the present study appear to be contradictory. This is, however, not the case, as we demonstrate in both studies the efficient activation of caspases by $\alpha$-toxin. Previously, we focused our investigations solely on the caspase activation pathway, but not on the mode of cell death induced by $\alpha$-toxin. Therefore, the use of zVAD-fmk was not essential for these experiments. Having noticed, however, that the $\alpha$-toxin-induced formation of hypodiploid nuclei was only partially inhibited in Jurkat-Bcl-2 cells, we performed additional studies using the pan caspase- 
inhibitory peptide zVAD-fmk, which enabled us to clearly demonstrate that caspases, although efficiently activated, are not essential for $\alpha$-toxin-induced cell death. Hence, our findings deliver a cautionary note that even caspase activation might not always be linked to an apoptotic phenotype, and should help to better understand the pathophysiological function of $S$. aureus.

\section{Materials and Methods}

\section{Cells, reagents and antibodies}

All cell lines were maintained in RPMI 1640, supplemented with $10 \%$ fetal calf serum, $10 \mathrm{mM}$ glutamine and antibiotics (all from Gibco BRL, Eggenstein, Germany). MCF-7 and MCF-7/CASP-3 breast carcinoma cells were described recently. ${ }^{33}$ Jurkat cells stably transfected with $\mathrm{Bcl}-2$ or empty vector alone were a gift from $\mathrm{H}$ Walczak (Heidelberg, Germany). The protease inhibitors aprotinin, antipain, pepstatin, leupeptin and phenylmethylsulfonyl fluoride (PMSF) as well as etoposide, RNase A, proteinase $\mathrm{K}$ and $S$. aureus $\alpha$-toxin that showed a single band on a SDS polyacrylamide gel $^{32}$ were purchased from Sigma (Deisenhofen, Germany). The neutralizing polyclonal sheep anti- $\alpha$-toxin antibody that was used at a 1:100 dilution was from Toxin Technology (Sarasota, FL, USA). The various death stimuli such as anti-CD95 mAb (BioCheck, Münster, Germany), $\mathrm{H}_{2} \mathrm{O}_{2}$ and etoposide were always used at concentrations of $1 \mu \mathrm{g} / \mathrm{ml}, 200 \mu \mathrm{M}$ and $100 \mu \mathrm{M}$, respectively. DNase I, which was used at a concentration of $400 \mathrm{U} / \mathrm{ml}$ was purchased from Roche Molecular Biochemicals (Mannheim, Germany). The fluorogenic caspase substrate DEVD-AMC ( $N$-acetyl-Asp-Glu-Val-Asp-aminomethyl-coumarin) was from BIOMOL (Hamburg, Germany), FITC-VAD-fmk was from Promega and annexin V-FITC was purchased from BD Biosciences (Heidelberg, Germany). The caspase-inhibitory peptide zVAD-fmk that was always used at $50 \mu \mathrm{M}$ was from Enzyme Systems (Dublin, CA, USA). The polyclonal goat antibodies recognizing the proform and the active subunits of caspase- 3 were from R\&D Systems (Minneapolis, USA) and the monoclonal HMGB1 antibody was from Pharmingen.

\section{Bacterial strains, cultures and supernatants}

Culture conditions and preparation of the supernatant of the $S$. aureus strain Wood 46 were described previously. ${ }^{32}$

\section{Preparation of cell extracts and Western blotting}

Cell extracts were prepared as described. ${ }^{53}$ To confirm equal loading, protein concentrations were determined with the BioRad protein assay (BioRad, Munich, Germany). Proteins were separated in SDS-polyacrylamide gels, and subjected to Western blotting. The proteins were visualized by enhanced chemiluminescent staining using ECL reagents (Amersham, Freiburg, Germany).

\section{Cell death assays}

Cell death was assessed by various methods including microscopic examination of trypan blue-stained cells, in which a minimum of 100 cells, each on four different fields of a hemocytometer, was counted. Cell death was also determined by the uptake of $\mathrm{PI}(2 \mu \mathrm{g} / \mathrm{ml}$; Sigma) in the absence or presence of annexin V-FITC into nonfixed cells, and subsequent flow cytometric analyses using the FSC/FL2 profile as described previously. ${ }^{54}$ For each determination, a minimum of 10000 cells was analysed. Lactate dehydrogenase (LDH) activity in supernatants of cells was assessed according to the protocol of the manufacturer (Roche Molecular Biochemicals). The standard crystal violet assay was employed as an alternative cell death measurement that is based on the staining of viable cells, and was performed as described. ${ }^{53}$

\section{Determination of intracellular ATP levels}

ATP levels were determined using the ATP Bioluminescence Assay Kit CLS II (Roche Molecular Biochemicals). Cells were collected by centrifugation at $4{ }^{\circ} \mathrm{C}$ and washed with PBS. The cell pellet was resuspended in $50 \mu$ of ice-cold lysis buffer $(100 \mathrm{mM}$ Tris- $\mathrm{HCl}$ and $4 \mathrm{mM}$ EDTA, pH 7.75), followed by the addition of $150 \mu$ of boiling lysis buffer. The samples were incubated for $2 \mathrm{~min}$ at $99^{\circ} \mathrm{C}$. Cell lysates were centrifuged at $10000 \mathrm{rpm}$ for $1 \mathrm{~min}$ at $4^{\circ} \mathrm{C}$, and supernatants were collected. ATP measurement was performed using $50 \mu \mathrm{l}$ of supernatant and $50 \mu$ l of luciferase reagent. The chemiluminescence was measured in a luminometer.

\section{Determination of DNA fragmentation}

The proportion of nuclei containing hypodiploid DNA was determined as previously described. ${ }^{54}$ Briefly, apoptotic nuclei were prepared by lysing cells in a hypotonic lysis buffer $(0.1 \%$ sodium citrate, $0.1 \%$ Triton $X-100$, $50 \mu \mathrm{g} / \mathrm{ml}$ propidium iodide), and subsequently analysed by flow cytometry on a FACScalibur (Becton Dickinson, Heidelberg, Germany) using CellQuest analysis software. For each determination, a minimum of 10000 cells was analyzed. Internucleosomal DNA fragmentation was assessed using conventional agarose gel electrophoresis (CAGE). Cellular DNA was prepared by lysing $5 \times 10^{6}$ Jurkat cells in $0.2 \mathrm{ml}$ of $0.5 \times$ TE buffer (20 mM Tris, $0.5 \mathrm{mM}$ EDTA, pH 8.0) containing $0.25 \% \mathrm{NP}-40$ and $50 \mu \mathrm{g}$ RNase $\mathrm{A}$ at $37^{\circ} \mathrm{C}$ for $30 \mathrm{~min}$. Proteinase $\mathrm{K}(200 \mu \mathrm{g} / \mathrm{sample})$ was added, and the samples were incubated for another $30 \mathrm{~min}$ at $37^{\circ} \mathrm{C}$. DNA sample buffer was added and aliquots were analyzed on $1.6 \%$ agarose gels. High molecular weight DNA fragmentation was determined by pulsed field gel electrophoresis (PFGE) as described. ${ }^{55}$ Jurkat cells were resuspended in PBS, mixed with low melting agarose, cast into blocks and cut into slices. The slices were incubated in EC buffer $(\mathrm{pH} 7.5 ; 6 \mathrm{mM}$ Tris- $\mathrm{HCl}, 1 \mathrm{M} \mathrm{NaCl}$, $0.1 \mathrm{M}$ EDTA, $0.5 \%$ Brij-58, $0.2 \% \mathrm{Na}$ deoxycholate, $0.5 \% \mathrm{Na}$ lauroyl sarcosine, $35 \mu \mathrm{g} / \mathrm{ml}$ RNase $\mathrm{H}$ ) at $37^{\circ} \mathrm{C}$ for $2 \mathrm{~h}$, followed by TE buffer ( $10 \mathrm{mM}$ Tris- $\mathrm{HCl}, 1 \mathrm{mM}$ EDTA, $100 \mu \mathrm{g} / \mathrm{ml}$ proteinase $\mathrm{K}$ ) at $50^{\circ} \mathrm{C}$ overnight. Agarose slices of stimulated cells were loaded directly into the gel slots; those of unstimulated cells were incubated at $37^{\circ} \mathrm{C}$ for $2 \mathrm{~h}$ with the respective agents, as detailed in the figure legends. Agarose gels (1\%) were run in $0.5 \times$ TBE buffer ( $\mathrm{pH} 8 ; 45 \mathrm{mM}$ Tris, $45 \mathrm{mM}$ boric acid, $1 \mathrm{mM}$ EDTA) using a CHEF-DR II electrophoresis cell (BioRad) under the following conditions: $14^{\circ} \mathrm{C}, 5-50 \mathrm{~s}$ switch time, $120^{\circ}$ angle and $6 \mathrm{~V} / \mathrm{cm}$.

\section{Fluorimetric determination of caspase-3 activity and caspase staining}

Caspase-3 activity was measured using the fluorogenic DEVD-AMC substrate as previously described. ${ }^{32}$ The catalytic activities are given in arbitrary units $(\mathrm{AU})$. For double stainings of necrotic membrane damage and caspase activation, cells were incubated for $20 \mathrm{~min}$ at $37^{\circ} \mathrm{C}$ with the pan-caspase in situ marker FITC-VAD-fmk in PBS at a final concentration of $10 \mu \mathrm{M}$, followed by staining with propidium iodide and subsequent flow cytometric analyses as described above. 


\section{Electron microscopy}

Cells were fixed in $2.5 \%$ glutaraldehyde in $100 \mathrm{mM}$ cacodylate buffer, $\mathrm{pH}$ 7.35 , for $1 \mathrm{~h}$ at room temperature. After six washes of $15 \mathrm{~min}$ with $100 \mathrm{mM}$ cacodylate buffer, the cells were incubated with $1 \%$ osmium tetroxide for $1 \mathrm{~h}$ at room temperature. The cells were then washed five times for $10 \mathrm{~min}$ in water before embedding, and all other procedures were essentially performed as described. ${ }^{56}$

\section{Acknowledgements}

We thank W Magura and C Reimertz for assistance with the ATP assays, $\checkmark$ Buchwalow for electron microscopy and S Weber for PFGE. This work was supported by grants from the Interdisciplinary Center of Clinical Research of the University of Münster and the Deutsche Forschungsgemeinschaft.

\section{References}

1. Leist $M$ and Jäättelä $M(2001)$ Four deaths and a funeral: from caspases to alternative mechanisms. Nat. Rev. 2: 1-10

2. Cryns V and Yuan J (1998) Proteases to die for. Genes Dev. 12: 1551-1570

3. Stroh C and Schulze-Osthoff K (1998) Death by a thousand cuts: an ever increasing list of caspase substrates. Cell Death Differ. 5: 997-1000

4. Borner $C$ and Monney L (1999) Apoptosis without caspases: an inefficient molecular guillotine? Cell Death Differ. 6: 497-507

5. Xiang J, Chao DT and Korsmeyer SJ (1996) Bax-induced cell death may not require interleukin 1-converting enzyme-like proteases. Proc. Natl. Acad. Sci. USA 93: 14559-14563

6. Miller TM, Mouldner KL, Knudson CM, Creedon DJ, Deshmukh M, Korsmeyer SJ and Johnson Jr EM (1997) Bax deletion further orders the cell death pathway in cerebellar granule cells and suggests a caspase-independent pathway to cell death. J. Cell Biol. 139: 205-217

7. McCarthy NJ, Whyte MKB, Gilbert CS and Evan GI (1997) Inhibition of Ced-3/ICE-related proteases does not prevent cell death induced by oncogenes, DNA damage, or the Bcl-2 homologue Bak. J. Cell Biol. 136: 215-227

8. Doerfler P, Forbush KA and Perlmutter RM (2000) Caspase enzyme activity is not essential for apoptosis during thymocyte development. J. Immunol. 164: 4071-4079

9. Petit F, Arnoult D, Lelievre JD, Parseval LM, Hance AJ, Schneider P, Corbeil J, Ameisen JC and Estaquier J (2001) Productive HIV-1 infection of primary CD4+ $T$ cells induces mitochondrial membrane permeabilization leading to a caspase-independent cell death. J. Biol. Chem. 277: 1477-1487

10. Berndt C, Mopps B, Angermuller S, Gierschik P and Krammer PH (1998) CXCR4 and CD4 mediate a rapid CD95-independent cell death in $\mathrm{CD4}^{+} \mathrm{T}$ cells. Proc. Natl. Acad. Sci. USA 95: 12556-12561

11. Mateo V, Lagneaux L, Bron D, Biron G, Armant M, Delespesse G and Sarfati M (1999) CD47 ligation induces caspase-independent cell death in chronic lymphocytic leukemia. Nat. Med. 5: 1277-1284

12. Pettersen RD, Bernard G, Olafsen MK, Pourtein M and Lie SO (2001) CD99 signals caspase-independent T cell death. J. Immunol. 166: 4931-4942

13. Sarin A, Williams MS, Alexander-Miller MA, Berzofsky JA, Zacharchuk CM and Henkart PA (1997) Target cell lysis by CTL granule exocytosis is independent of ICE/Ced-3 family proteases. Immunity 6: 209-215

14. Lavoie JN, Nguyen M, Marcellus RC, Branton PE and Shore GC (1998) E4orf4, a novel adenovirus death factor that induces p53-independent apoptosis by a pathway that is not inhibited by zVAD-fmk. J. Cell Biol. 140: $637-645$

15. Nylandsted J, Rohde M, Brand K, Bastholm L, Elling F and Jäättelä M (2000) Selective depletion of heat shock protein 70 (Hsp70) activates a tumor-specific death program that is independent of caspases and bypasses Bcl-2. Proc. Natl. Acad. Sci. USA 97: 7871-7876

16. Eguchi Y, Shimizu S and Tsujimoto Y (1997) Intracellular ATP levels determine cell death fate by apoptosis or necrosis. Cancer Res. 57: 1835-1840
17. Leist M, Single B, Castoldi AF, Kuhnle S and Nicotera P (1997) Intracellular adenosine triphosphate (ATP) concentration: a switch in the decision between apoptosis and necrosis. J. Exp. Med. 185: 14811486

18. Holler N, Zaru R, Micheau O, Thome M, Attinger A, Valitutti S, Bodmer JL, Schneider P, Seed B and Tschopp J (2000) Fas triggers an alternative, caspase-8-independent cell death pathway using the kinase RIP as effector molecule. Nat. Immunol. 1: 489-495

19. Denecker G, Vercammen D, Declercq W and Vandenabeele P (2001) Apoptotic and necrotic cell death induced by death domain receptors. Cell. Mol. Life Sci. 58: $356-370$

20. Lowy FD (1998) Staphylococcus aureus infections. N. Engl. J. Med. 339: 520-532

21. Marrack P and Kappler J (1990) The staphylococcal enterotoxins and their relatives. Science 240: 705-711

22. Weinrauch $Y$ and Zychlinsky $A$ (1999) The induction of apoptosis by bacterial pathogens. Annu. Rev. Microbiol. 53: 155-187

23. Gao LY and Kwaik YA (2000) Hijacking of apoptotic pathways by bacterial pathogens. Microbes Infect. 2: 1705-1719

24. Jonas D, Walev I, Berger T, Liebetrau M, Palmer M and Bhakdi S (1994) Novel path to apoptosis: small transmembrane pores created by staphylococcal $\alpha$ toxin in T lymphocytes evoke internucleosomal DNA degradation. Infect. Immun. 62: 1304-1312

25. Bayles KW, Wesson CA, Liou LE, Fox LK, Bohach GA and Trumble WR (1998) Intracellular Staphylococcus aureus escapes the endosome and induces apoptosis in epithelial cells. Infect. Immun. 66: 336-342

26. Menzies BE and Kourteva I (1998) Internalization of Staphylococcus aureus by endothelial cells induces apoptosis. Infect. Immun. 66: 5994-5998

27. Tucker KA, Reilly SS, Leslie CS and Hudson MC (2000) Intracellular Staphylococcus aureus induces apoptosis in mouse osteoblasts. FEMS Microbiol. Lett. 186: 151-156

28. Nuzzo I, Sanges MR, Folgore A and Carratelli CR (2000) Apoptosis of human keratinocytes after bacterial invasion. FEMS Immunol. Med. Microbiol. 27: $235-240$

29. Wesson CA, Deringer J, Liou LE, Bayles KW, Bohach GA and Trumble WR (2000) Apoptosis induced by Staphylococcus aureus in epithelial cells utilizes a mechanism involving caspases 8 and 3. Infect. Immun. 68: 2998-3001

30. Song L, Hobaugh MR, Shustak C, Cheley S, Bayley H and Gouaux JE (1996) Structure of staphylococcal $\alpha$-hemolysin, a heptameric transmembrane pore. Science 274: 1859-1866

31. Valeva A, Palmer M and Bhakdi S (1997) Staphylococcal $\alpha$-toxin: formation of the heptameric pore is partially cooperative and proceeds through multiple intermediate stages. Biochemistry 36: 13298-13304

32. Bantel H, Sinha B, Domschke W, Peters G, Schulze-Osthoff $K$ and Jänicke RU (2001) $\alpha$-toxin is a mediator of Staphylococcus aureus-induced cell death and activates caspases via the intrinsic death pathway independently of death receptor signaling. J. Cell Biol. 155: 637-647

33. Jänicke RU, Sprengart ML, Wati MR and Porter AG (1998) Caspase-3 is required for DNA fragmentation and morphological changes associated with apoptosis. J. Biol. Chem. 273: 9357-9360

34. Scaffidi P, Mistell T and Blanchi ME (2002) Release of chromatin protein HMGB1 by necrotic cells triggers inflammation. Nature 488: 191-195

35. Scaffidi C, Fulda S, Srinivasan A, Friesen C, Li F, Tomaselli KJ, Debatin KM, Krammer PH and Peter ME (1998) Two CD95 (APO-1/Fas) signaling pathways. EMBO J. 17: 1675-1687

36. Ferrari D, Stepczynska A, Los M, Wesselborg S and Schulze-Osthoff K (1998) Differential regulation and ATP requirement for caspase-8 and caspase-3 activation during CD95- and anticancer drug-induced apoptosis. J. Exp. Med. 188: $979-984$

37. Smith KG, Strasser A and Vaux DL (1996) CrmA expression in T lymphocytes of transgenic mice inhibits CD95 (Fas/APO-1)-transduced apoptosis, but does not cause lymphadenopathy or autoimmune disease. EMBO J. 15: 5167-5176

38. Chautan M, Chazal G, Cecconi F, Gruss P and Golstein P (1999) Interdigital cell death can occur through a necrotic and caspase-independent pathway. Curr. Biol. 9: 967-970

39. Bortner CD, Hughes FM and Cidlowski JA (1997) A primary role for $\mathrm{K}^{+}$and $\mathrm{Na}^{+}$ efflux in the activation of apoptosis. J. Biol. Chem. 272: 32436-32442 
40. Dallaporta B, Marchetti P, de Pablo MA, Maisse C, Duc HT, Métivier D, Zamzami N, Geuskens M and Kroemer G (1999) Plasma membrane potential in thymocyte apoptosis. J. Immunol. 162: 6534-6542

41. Maeno E, Ishizaki Y, Kanaseki T, Hazama A and Okada Y (2000) Normotonic cell shrinkage because of disordered volume regulation is an early prerequisite to apoptosis. Proc. Natl. Acad. Sci. USA 97: 9487-9492

42. Hughes Jr FM, Bortner CD, Purdy GD and Cidlowski JA (1997) Intracellular $\mathrm{K}^{+}$ suppresses the activation of apoptosis in lymphocytes. J. Biol. Chem. 272: 30567-30576

43. Warny M and Kelly CP (1999) Monocytic cell necrosis is mediated by potassium depletion and caspase-like proteases. Am. J. Physiol. 276: 717-724

44. Liu X, Zou H, Slaughter $C$ and Wang X (1997) DFF, a heterodimeric protein that functions downstream of caspase-3 to trigger DNA fragmentation during apoptosis. Cell 89: 175-184

45. Enari M, Sakahira H, Yokoyama H, Okawa K, Iwamatsu A and Nagata S (1998) A caspase-activated DNase that degrades DNA during apoptosis, and its inhibitor ICAD. Nature 391: 43-50

46. Daugas E, Susin SA, Zamzami N, Ferri KF, Irinopoulou T, Larochette N, Prevost MC, Leber B, Andrews D, Penninger J and Kroemer G (2000) Mitochondrionuclear translocation of AIF in apoptosis and necrosis. FASEB J. 14: 729-739

47. Braun JS, Novak R, Murray PJ, Eischen CM, Susin SA, Kroemer G, Halle A, Weber JR, Tuomanen El and Cleveland JL (2001) Apoptosis-inducing factor mediates microglial and neuronal apoptosis caused by pneumococcus. J. Infect. Dis. 184: 1300-1309

48. Squier MKT and Cohen JJ (1996) Calpain and cell death. Cell Death Differ. 3: 275-283
49. Deis LP, Galinka H, Berissi H, Cohen O and Kimchi A (1996) Cathepsin D protease mediates programmed cell death induced by interferon, Fas/APOand TNF-alpha. EMBO J. 15: 3861-3870

50. Foghsgaard L, Wissing D, Mauch D, Lademann U, Bastholm L, Boes M, Elling $F$, Leist $M$ and Jäättelä $M(2001)$ Cathepsin $B$ acts as a dominant execution protease in tumor cell apoptosis induced by tumor necrosis factor. J. Cell Biol. 153: 999-1009

51. Wright SC, Schellenberger U, Wang H, Kinder DH, Talhouk JW and Larrick JW (1997) Activation of CPP32-like proteases is not sufficient to trigger apoptosis: inhibition of apoptosis by agents that suppress activation of AP24, but not CPP32-like activity. J. Exp. Med. 186: 1107-1117

52. Williams MS and Henkart PA (1994) Apoptotic cell death induced by intracellular proteolysis. J. Immunol. 153: 4247-4255

53. Jänicke RU, Lin XY, Lee FHH and Porter AG (1996) Cyclin D3 sensitizes tumor cells to tumor necrosis factor-induced, c-Myc-dependent apoptosis. Mol. Cell Biol. 16: 5245-5253

54. Wesselborg S, Engels $I H$, Rossmann E, Los M and Schulze-Osthoff $K$ (1999) Anticancer drugs induce caspase-8/FLICE activation and apoptosis in the absence of CD95 receptor/ligand interaction. Blood 93: 3053-3063

55. Goering RV and Winters MA (1992) Rapid method for epidemiological evaluation of gram-positive cocci by field inversion gel electrophoresis. J. Clin. Microbiol. 30: 577-580

56. Schulze-Osthoff K, Krammer PH and Dröge W (1994) Divergent signalling via APO-1/Fas and the TNF receptor, two homologous molecules involved in physiological cell death. EMBO J. 13: 4587-4596 